\title{
Avoin vertaisarviointi: hyötyjen ja haasteiden tasapainottelua
}

\author{
Mikael Laakso \\ Hanken Svenska Handelshögskolan \\ mikael.laakso@hanken.fi \\ https://orcid.org/0000-0003-3951-7990
}

Riitta Jytilä

Turun yliopisto

riijyt@utu.fi

https://orcid.org/0000-0002-1165-3926

Susanna Nykyri

Tampereen teknillisen yliopiston kirjasto

susanna.nykyri@tut.fi

https://orcid.org/0000-0002-5018-5176

Riitta Koikkalainen

Kansalliskirjasto

riitta.koikkalainen@helsinki.fi

https://orcid.org/0000-0003-3289-1832

Asiasanat: vertaisarviointi; avoin tieto; tiedelehdet; toimitustyö

Avoin julkaiseminen on kahden viime vuosikymmenen aikana edistynyt hitaasti mutta varmasti. Vaikka maksumuurit madaltuvat kaiken aikaa ja tekniset edellytykset ovat jo olemassa, niin julkaistun aineiston avoimuuden kasvu ei ole tuonut mukanaan merkittävästi avoimempia käytäntöjä itse tiedelehtien aineistojen kokoamiseen ja siihen liittyviin prosesseihin. Vertaisarviointi ei ole juuri muuttuneet, ja se on säilynyt selvästi erillään itse julkaistavasta lopputuotteesta. 
Se on käsitetty lähinnä aineiston tuotanto- ja valikointiprosessina, jolla itsessään ei ole merkitystä osana pysyvämpää tieteellistä viestintää.

Edellä kuvattu staattinen ymmärrys vertaisarvioinnista on kuitenkin myös haastettu. Esimerkiksi Tony Ross-Hellauer (2017) kollegoineen ehdottaa että avoin vertaisarviointi ymmärrettäisiin monia, osin päällekkäisiäkin vertaisarviomalleja mahdollistavana sateenvarjokäsitteenä. Avoimen vertaisarvioinnin muotoja ja määritelmiä on paljon, ja kaikista niistä löytyy jokin seuraavista näkökulmista, mutta vaihtelevin painotuksin:

1. Vertaisarvioijien nimet julkaistaan hyväksytyn käsikirjoituksen yhteydessä.

2. Vertaisarviot julkaistaan avoimesti.

3. Vertaisarviointi ei perustu suljettuun kutsumenettelyyn vaan on auki laajemmalle yleisölle ennen julkaisua.

Avoimuuden monista mahdollisista asteista huolimatta vain muutamat lehdet ja julkaisijat ovat toistaiseksi lähteneet lisäämään avoimuutta, niistä merkittävinä esimerkkeinä BioMed Central -lehdet ja F10oo Research-lehti. Näissä vertaisarviot, ja kirjoittajien mahdolliset vastaukset niihin, ovat kaikkien artikkeleiden ohella nähtävissä. Näyttäisi siltä että käytäntö arvioiden julkaisemisessa on leviämässä myös laajemmin etenkin luonnontieteissä, joissa kasvava määrä lehtiä ja julkaisijoita on allekirjoittanut yhteisen lausuman (ks. ASAPbio, ei pvm.).

Osana vertaisarviointia koskevaa kansallista selvitystä lähetimme kesällä 2018 kotimaisten tiedelehtien parissa toimiville verkkokyselyn ja keräsimme kotimaisilta vertaisarviointia käyttäviltä kirjakustantajilta haastatteluita. Tavoitteena oli selvittää, miten nykyisen vertaisarviointiprosessin koetaan toimivan sekä miten vastaajat näkevät avoimuuden lisäämisen vaikuttavuuden tutkimuksen ja julkaisemisen kentällä.

Kyselyyn vastasi 98 vastaajaa. Kyselyn tuloksista nousi esiin monia ristiriitaisuuksia, jotka vaativat lehdiltä tasapainottelua sen suhteen, minkälaisia valintoja avoimuuden suhteen ne tekevät. Hyvä esimerkki pohdinnoista on suhtautuminen lausuntojen julkisuuteen. Suurin osa vastaajista oli sitä mieltä, että avoimet vertaisarviolausunnot parantaisivat lausuntojen laatua. Toisaalta kuitenkin arvioijien rekrytointi nähtiin haasteellisempana, mikäli lausunto julkaistaan avoimesti itse artikkelin rinnalla. Lehden toimituskunta joutuu siis punnitsemaan valintojaan tietynlaisessa ristipaineessa. Tuloksista ilmeni lisäksi, että avoimuuden nähtiin vaikuttavan myös itse arvion sisältöön. Lausuntoa kirjoittava vertaisarvioija saattaa esimerkiksi vältellä kriittisimpiä näkemyksiään välttääkseen mahdollisia ristiriitatilanteita. 
Avointa julkaisemista on monessa yhteydessä edistetty erilaisilla pakotteilla ja vahvoilla kannustimilla. Päätelmämme kerätyn aineiston pohjalta on, että tällaiset yksinkertaiset ja hyvin yleisellä tasolla tehtävät linjaukset eivät sovellu kovinkaan hyvin avoimen vertaisarvioinnin edistämiseksi. Parasta olisi, jos jokainen lehti ja kustantaja arvioisi omista lähtökohdistaan sekä lehden erityisten intressien kannalta, mitkä avoimen vertaisarvioinnin osa-alueista olisi kannattavaa ottaa käyttöön.

\section{Lähteet}

ASAPbio. (ei pvm.). Open letter on the publication of peer review reports. ASAPbio. http:// asapbio.org/letter

Ross-Hellauer, T. (2017). What is open peer review? A systematic review. F1oooResearch, 6, 588. https://doi.org/10.12688/f1000research.11369.1 